\title{
Synthesis of Globin Chains in Sickle $\beta$-Thalassemia
}

\author{
Frances M. Gill and Elias SchwarTz \\ From the Cardeza Foundation for Hematologic Research and the Department \\ of Pediatrics, Jefferson Medical College, Philadelphia, Pennsylvania 19107 \\ and the Children's Hospital of Philadelphia and the Department of Pediatrics, \\ University of Pennsylvania School of Medicine, Philadelphia, Pennsylvania 19146
}

\begin{abstract}
A в S T R A C T In five patients with sickle $\beta$-thalassemia there was balanced $\alpha$ - and $\beta$-globin synthesis in the bone marrow and decreased total $\beta$-chain synthesis relative to that of $\alpha$-chain in the peripheral blood. These findings are similar to those in patients with simple $\beta$ thalassemia trait. Despite a range of hemoglobin concentrations from 6.8 to $12.5 \mathrm{~g} / 100 \mathrm{ml}$ in the patients with sickle thalassemia, there was no evidence of a significant excess of $\alpha$-chains in the red cells of the bone marrow which could contribute to the hemolysis and anemia.
\end{abstract}

In patients heterozygous for $\beta$-thalassemia the capacity to synthesize $\beta$-chain decreases more rapidly than that for $\alpha$-chain. In nonthalassemic subjects the rates of $\beta$ - and $\alpha$-chain synthesis decrease equally as the red cell matures. The $\beta^{\mathrm{S}}$ - and $\beta^{\mathbf{A}}$-chains serve as convenient markers for globin synthesis due to the nonthalassemic and thalassemic alleles in patients with sickle $\beta$-thalassemia. The unbalanced globin synthesis in the peripheral blood of these patients is explained by the decrease in relative synthesis of $\beta^{\mathbf{s}}$-chain, in comparison with that of $\alpha$-chain. This instability is not present in sickle cell trait. The $\beta^{\mathrm{A}}$-chain synthesis was only unstable in the two patients who had the most marked anemia. The major mechanism for achieving balanced globin production in the bone marrow in the presence of one thalassemic gene appears to be increased synthesis of $\beta$-chain due to the nonthalassemic allele. In addition, there may be a decrease of total $\alpha$-chain synthesis in some patients.

\section{INTRODUCTION}

In $\beta$-thalassemia there is decreased synthesis of the $\beta$ chain of normal adult hemoglobin ( $\mathrm{Hb} \mathrm{A}$ ) in the pe-

This work was presented in part at the National Meeting of the American Federation for Clinical Research. Atlantic City, N. J. May 1972.

A preliminary report has appeared in abstract form (1).

Received for publication 5 May 1972 and in revised form 5 July 1972. ripheral blood. These measurements of the last stages of hemoglobin synthesis in the reticulocyte do not reflect accurately the relative synthesis of globin chains throughout the major period of red cell maturation in the bone marrow. In heterozygous $\beta$-thalassemia, $\beta$ chain synthesis in the reticulocytes is approximately one-half that of $\alpha$-chain (2-5), while in the bone marrow of two patients there was balanced synthesis of globin chains similar to that found in controls (6). In homozygous $\beta$-thalassemia, the production of $\beta$-chain is less than $25 \%$ that of $\alpha$-chain in peripheral blood (2-5), but in the bone marrow it is frequently somewhat higher $(7,8)$. The findings in the heterozygotes in particular suggest that the nucleated red cell is able to compensate for the depression of $\beta$-chain synthesis due to the thalassemic gene and to maintain balanced globin synthesis. After the loss of the nucleus the red cell is no longer able to compensate, and decreased $\beta$-chain production in relation to that of $\alpha$-chain becomes apparent.

In this study the structurally abnormal $\beta$-chain in patients with sickle $\beta$-thalassemia was used as a marker to distinguish between the synthesis of $\beta$-chains due to the thalassemic and nonthalassemic genes in the bone marrow and peripheral blood. In addition, the relationship between globin synthesis and clinical severity in sickle $\beta$-thalassemia was investigated. Five patients with sickle $\beta$-thalassemia in whom $\mathrm{Hb} \mathrm{A}$ was present in decreased amounts were chosen so that the synthesis of $\beta^{\mathrm{S}}-, \beta^{\mathbf{\Lambda}}$ - and $\alpha$-chains could be studied and compared.

\section{METHODS}

Patients. The patients studied included four American Negroes and one Italian with sickle $\beta$-thalassemia, and three Italians and one Iraqi with $\beta$-thalassemia trait. The five patients with sickle $\beta$-thalassemia each had greater than $68 \%$ $\mathrm{Hb} \mathrm{S}, 7-22 \% \mathrm{Hb} \mathrm{A}$, and red cell morphology consistent with the disorder (Table I). Patient G. P. had his spleen removed $3 \mathrm{yr}$ before this study. Two of the Italian patients with $\beta$-thalassemia trait (E. D. and J. C.) were parents of children with severe homozygous $\beta$-thalassemia in whom $\beta$-chain 
TABLE I

Hematologic Data

\begin{tabular}{|c|c|c|c|c|c|c|c|c|c|}
\hline Subject & Age & Hemoglobin & Hematocrit & $\begin{array}{l}\text { Red blood } \\
\text { cells }\end{array}$ & Reticulocytes & $\mathrm{Hb} \mathrm{A}_{2}$ & $\mathrm{Hb} \mathrm{F}$ & $\mathrm{Hb} \mathrm{A}$ & $\mathrm{Hb} \mathrm{S}$ \\
\hline & $y r$ & $\mathrm{~g} / 100 \mathrm{ml}$ & $\%$ & $10^{-6} / \mathrm{mm}^{3}$ & $\%$ & $\%$ & $\%$ & $\%$ & $\%$ \\
\hline \multicolumn{10}{|c|}{ Sickle $\beta$-thalassemia } \\
\hline K. E. & 29 & 12.5 & 39 & 5.31 & 3.8 & 5.2 & 4.8 & 22.0 & 68.0 \\
\hline G. P. & 19 & 12.2 & 37 & 5.26 & 1.5 & $*$ & 10.0 & 7.0 & 83.0 \\
\hline E. W. & 48 & 11.6 & 37 & 5.05 & 1.4 & $*$ & 0.8 & 8.7 & 90.5 \\
\hline M. F. & 35 & 8.7 & 26 & 3.77 & 2.0 & $*$ & 4.4 & 14.6 & 81.0 \\
\hline S. B. & 21 & 6.8 & 25 & 3.09 & 4.5 & 4.2 & 1.0 & 13.3 & 81.5 \\
\hline \multicolumn{10}{|c|}{$\beta$-thalassemia trait } \\
\hline J. C. & 43 & 11.0 & 38 & 5.45 & 4.3 & 5.0 & 2.7 & 92.3 & 0 \\
\hline H. A. & 28 & 13.7 & 44 & 6.90 & 2.8 & 5.0 & 0.8 & 94.2 & 0 \\
\hline V. C. & 41 & 13.7 & 44 & 6.39 & 0.9 & 4.5 & 1.0 & 94.5 & 0 \\
\hline L. S. & 28 & 9.8 & 32 & 5.14 & 2.7 & 5.2 & 0.6 & 94.2 & 0 \\
\hline
\end{tabular}

* Not done.

production was not totally absent. All the patients with $\beta$-thalassemia trait had increased levels of $\mathrm{Hb} \mathrm{A}_{2}$. Four nonthalassemic control subjects with hemolytic anemia were also studied.

Clinical studies. Hematologic values were determined by standard methods (9). The percentages of $\mathrm{Hb} \mathrm{A}_{2}$ in patients with thalassemia trait and $\mathrm{Hb} \mathrm{S}$ in those with sickle thalassemia were determined by starch block electrophoresis (10). The normal range for $\mathrm{Hb} \mathrm{A}_{2}$ by this method in our laboratory is $1.8-3.3 \%$ (mean $\pm 2 \mathrm{SD}$ ). Fetal hemoglobin ( $\mathrm{Hb} \mathrm{F}$ ) was measured by the alkali denaturation method (11). Normal subjects have less than $2 \% \mathrm{Hb} \mathrm{F}$.

Measurements of globin chain synthesis. $4 \mathrm{ml}$ of peripheral blood or bone marrow were incubated with $10-15 \mu \mathrm{Ci}$ of $\mathrm{L}-\left[\mathrm{U}-{ }^{14} \mathrm{C}\right]$ leucine $(100 \mu \mathrm{Ci} / 0.052 \mathrm{mg})$ in a metabolic shaker at $37^{\circ} \mathrm{C}$ for $2 \mathrm{~h}$, after which the red cells were washed and hemolyzed (12). The hemolysate was centrifuged at $15,000 \mathrm{~g}$ for $1 \mathrm{~h}$ to remove stroma. Globin was prepared as previously described (12). The globin chains were separated by column chromatography on carboxymethyl cellulose at $\mathrm{pH} 6.7$ in $8 \mathrm{M}$ urea $(12,13)$. The optical density at $280 \mathrm{~nm}$ of each of the collected fractions was measured in Gilford spectrophotometer (Gilford Instrument Laboratories, Inc., Oberlin, Ohio). Radioactivity of a $1.0 \mathrm{ml}$ sample from each tube was measured in a Packard Tri-Carb liquid scintillation counter (Packard Instrument Co., Inc., Downers Grove, Ill.) at $60 \%$ efficiency for ${ }^{14} \mathrm{C}(12)$. The total radioactivity of the peak containing each chain was determined by adding the separate radioactivities of the fractions contained in that peak. The relative synthesis of the two types of $\beta$-chain to $\alpha$-chain was expressed as the $\beta^{\mathbb{S}} / \alpha$ and the $\beta^{\boldsymbol{\Delta}} / \alpha$ ratios. The calculation of specific activity (counts per minute/optical density) for each chain was obtained by averaging the specific activities of the tubes comprising the height of each globin peak. The absorption of $\beta$-chain exceeds that of $\alpha$-chain by a factor of 1.52 at $\mathrm{pH} 6.7$ (12). An appropriate correction for this absorption difference at $280 \mathrm{~nm}$ was made in calculating the specific activities.

In one experiment two different methods were used to study bone marrow. In addition to incubating bone marrow aspirate as described above, $3.5 \mathrm{ml}$ of bone marrow were mixed with two volumes of 3\% dextran (Dextran 75, Abbot
Laboratories, N. Chicago, Ill.) and were allowed to sediment for $1 \mathrm{~h}(7)$. The nucleated cell fraction was recovered by centrifugation of the supernatant suspension. The recovered cells were suspended in $3 \mathrm{ml}$ of the patient's plasma containing $6 \mathrm{mg}$ of glucose, $10 \mu \mathrm{Ci}$ of $\left[{ }^{14} \mathrm{C}\right]$ leucine were added, and the mixture was incubated in a metabolic shaker at $37^{\circ} \mathrm{C}$ for $2 \mathrm{~h}$. At the end of the incubation a $3 \mathrm{ml}$ sample of centrifuged peripheral red blood cells from the patient was added as nonradioactive carrier. The remainder of the procedure for separating globin chains and measuring radioactivity was identical to that described above.

\section{RESULTS}

The hematologic values of the patients with $\beta$-thalassemia are summarized in Table I. Each patient had decreased red cell indices, hypochromia, microcytosis, and variations in red cell size and shape seen on the peripheral blood smear. In many of the patients the reticulocytes were increased. There was mild to moderate erythroid hyperplasia in the bone marrow of each of the patients. $\mathrm{Hb} \mathrm{A_{2 }}$ was elevated in each patient with thalassemia trait, and $\mathrm{Hb} \mathrm{F}$ was normal or only slightly increased. Because of the difficulty to obtaining clear separations of $\mathrm{Hb} \mathrm{S}$ and $\mathrm{Hb} \mathrm{A}_{2}$ by starch block electrophoresis, levels of $\mathrm{Hb} \mathrm{A_{2 }}$ were not determined in every patient with sickle thalassmia. The $\mathrm{Hb} \mathrm{A}_{2}$ in these patients was judged to be elevated on inspection of separations of the hemoglobins by starch gel electrophoresis. Since each of these patients had some $\mathrm{Hb} \mathrm{A}$ present, the diagnosis of sickle thalassemia was certain.

Table II summarizes the results of the studies of globin synthesis in the patients with $\beta$-thalassemia trait. The $\beta / \alpha$ ratios of specific activities in the peripheral blood were similar to those found in our laboratory in other $\beta$-thalassemia heterozygotes, $0.57 \pm 0.09$ ( $1 \mathrm{SD}$ ). The specific activity and radioactivity ratios in the 
TABLE II

Subunit Synthesis in $\beta$-Thalassemia Trait

\begin{tabular}{|c|c|c|c|c|}
\hline \multirow[b]{3}{*}{ Subject } & \multicolumn{2}{|c|}{ Peripheral blood ratios } & \multicolumn{2}{|c|}{ Bone marrow ratios } \\
\hline & $\begin{array}{l}\text { Specific } \\
\text { activity }\end{array}$ & $\begin{array}{l}\text { Radio- } \\
\text { activity }\end{array}$ & $\begin{array}{l}\text { Specific } \\
\text { activity }\end{array}$ & $\begin{array}{l}\text { Radio- } \\
\text { activity }\end{array}$ \\
\hline & $\beta / \alpha$ & $\beta / \alpha$ & $\beta / \alpha$ & $\beta / \alpha$ \\
\hline J. C. & 0.59 & 0.64 & $\begin{array}{l}1.00 \\
1.12^{*}\end{array}$ & $\begin{array}{l}1.06 \\
1.17^{*}\end{array}$ \\
\hline H. A. & 0.64 & 0.68 & 0.97 & 0.97 \\
\hline V.C. & 0.60 & 0.59 & 1.01 & 0.94 \\
\hline L. S. & 0.70 & 0.64 & 0.92 & 0.87 \\
\hline
\end{tabular}

* Nucleated cells separated by dextran sedimentation.

blood correspond closely to each other in these patients, indicating that the amounts of nonradioactive $\alpha$ - and $\beta$-chain in the blood are approximately equal. In the bone marrow studies both the radioactivity and specific activity ratios indicate approximately equal synthesis of $\alpha$ - and $\beta$-chains. These findings confirm those in two other patients with $\beta$-thalassemia trait previously studied in our laboratory (6). In the earlier experiments bone marrow globin synthesis was studied in nucleated red cells separated from bone marrow aspirate by dextran sedimentation. The results obtained by this method and by incubation of whole bone marrow aspirate were compared in the present study in patient J. C. The $\beta / \alpha$ ratio in sedimented cells was similar to that obtained on marrow which was not sedimented before incubation (Table II). The sedimented cells had a $\beta / \alpha$ specific activity ratio of 1.12 while the whole marrow had a lower ratio of 1.00 , perhaps reflecting the decreased ratio of 0.59 found in the reticulocytes of the peripheral blood contained in the aspirate. The radioactivity incorporated in the $\alpha$-chain in the whole bone marrow incubation was 12.4 times that incorporated in the $\alpha$-chain in an equal volume of peripheral blood, indicating that an adequate population of nucleated cells had been obtained.

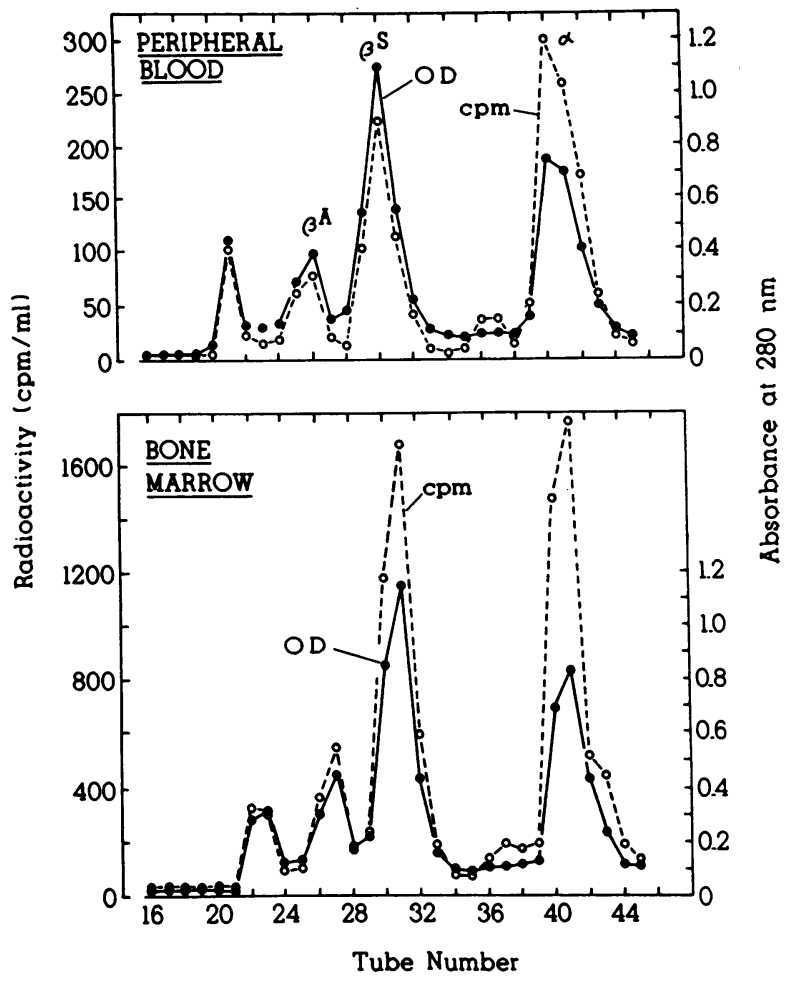

Figure 1 Chromatograms of globin from peripheral blood and bone marrow of patient $\mathrm{K}$. E. with sickle $\beta$-thalassemia. The $\left(\beta^{\mathbf{S}}+\beta^{\mathbf{A}}\right) / \alpha$ ratio of radioactivities in the peripheral blood is 0.78 , while in the bone marrow it is 1.09 .

In the remainder of the patients, bone marrow was incubated without prior sedimentation. In the experiments in which intact marrow aspirate was used, the radioactivity incorporated into globin chains was 3-25 times the amount incorporated into peripheral blood globin from the same patient drawn at the same time.

Fig. 1 shows a typical separation of globin chains from the peripheral blood and bone marrow of a patient with sickle thalassemia (K. E.). The results of globin synthesis studies in each of the patients with sickle $\beta$ thalassemia are summarized in Table III. The mean

TABLE III

Subunit Synthesis in Sickle $\beta$-Thalassemia

\begin{tabular}{|c|c|c|c|c|c|c|c|c|c|c|}
\hline \multirow[b]{3}{*}{ Subject } & \multicolumn{5}{|c|}{ Peripheral blood ratios } & \multicolumn{5}{|c|}{ Bone marrow ratios } \\
\hline & \multicolumn{2}{|c|}{ Specific activity } & \multicolumn{3}{|c|}{ Radioactivity } & \multicolumn{2}{|c|}{ Specific activity } & \multicolumn{3}{|c|}{ Radioactivity } \\
\hline & $\beta \mathrm{s} / \alpha$ & $\beta A / \alpha$ & $\beta \mathrm{s} / \alpha$ & $\beta A / \alpha$ & $(\beta \mathbf{S}+\beta \mathbf{A}) / \alpha$ & $\beta S / \alpha$ & $\beta \mathrm{A} / \alpha$ & $\beta^{\mathrm{s}} / \alpha$ & $\beta \Lambda / \alpha$ & $\left(\beta^{S}+\beta A\right) \alpha$ \\
\hline K. E. & 0.74 & 0.87 & 0.58 & 0.20 & 0.78 & 1.00 & 0.94 & 0.87 & 0.22 & 1.09 \\
\hline G. P. & 0.70 & 1.08 & 0.56 & 0.19 & 0.75 & 1.04 & 1.04 & 0.84 & 0.13 & 0.97 \\
\hline E. W. & 0.74 & 1.12 & 0.49 & 0.24 & 0.73 & 0.98 & 1.14 & 0.74 & 0.24 & 0.98 \\
\hline M. F. & 0.61 & 0.60 & 0.63 & 0.17 & 0.80 & 0.99 & 0.96 & 0.84 & 0.27 & 1.11 \\
\hline S. B. & 0.76 & 0.61 & 0.53 & 0.15 & 0.68 & 1.11 & 0.96 & 0.73 & 0.23 & 0.96 \\
\hline
\end{tabular}


$\left(\beta^{\mathrm{S}}+\beta^{\mathbf{A}}\right) / \alpha$ radioactivity ratio in the peripheral blood was 0.75 (range $0.68-0.80$ ), demonstrating unbalanced globin synthesis. In the bone marrow studies, total synthesis of $\beta$-chain was approximately equal to that of $\alpha$-chain, the mean $\left(\beta^{\mathbb{S}}+\beta^{\mathbf{A}}\right) / \alpha$ radioactivity ratio being $1.02(0.96-1.11)$. In each bone marrow study, the synthesis of $\beta^{\mathrm{S}}$-chains was greater than that of $\beta^{\mathbf{A}}$-chains by a factor of $3.1-6.5$, as indicated by the radioactivity ratios, demonstrating the presence of a thalassemic defect affecting the synthesis of $\beta^{\mathbf{A}}$-globin. In each patient the $\beta^{\mathrm{S}} / \alpha$ and $\beta^{\mathbf{A}} / \alpha$ ratios of specific activities in the bone marrow were close to one $(0.94-1.14)$, indicating that the relative amounts of these three chains synthesized in the bone marrow were similar to the relative amounts of these chains present in mature red cells.

A comparison of the specific activity ratios from the bone marrow samples with those of the peripheral blood indicates the changes in relative synthesis of globin chains which occur as the red cell matures into a reticulocyte (Table III). In each patient the $\beta^{\mathrm{s}} / \alpha$ ratio of specific activities in the peripheral blood is lower than in the bone marrow, the mean decrease being $31 \%$ $(25-38 \%)$. The $\beta^{\mathrm{s}} / \alpha$ ratio of specific activities in the peripheral blood compares the relative synthesis of $\beta^{\text {s }}$. and $\alpha$-chains with the relative sizes of the nonradioactive pools of these chains. In each patient the ratio was considerably lower than one, the mean ratio being $0.71(0.61-0.76)$. This figure confirms the finding of a decrease in $\beta^{\mathrm{s}} / \alpha$ from bone marrow to peripheral blood of $31 \%$, and indicates a more rapid loss of synthetic activity for $\beta^{\mathrm{s}}$-chain than for $\alpha$-chain.

In two of the patients (M. F. and S. B.) the $\beta^{\mathrm{A}} / \alpha$ ratio of specific activities was also decreased to a similar degree ( 38 and $37 \%$ ). This finding suggests a more rapid decline of $\beta^{\mathbf{A}}$ - and $\beta^{\mathbf{S}}$-synthesis than that of $\alpha$ chain in these patients. In the other three patients (K. E., G. P., and E. W.) the $\beta^{\mathbf{A}} / \alpha$ ratios of specific activities in peripheral blood and bone marrow were similar. In these patients the synthesis of $\beta^{\mathbf{s}}$-chain appeared to decline more rapidly than either that of $\beta^{A}$ - or $\alpha$-chain.

The $\beta / \alpha$ specific activity ratios in peripheral blood in controls in our laboratory were $0.99 \pm 0.05$ (1 SD). In four nonthalassemic patients studied as controls, the $\beta / \alpha$ ratios in the bone marrow were $0.94-1.06$.

\section{DISCUSSION}

In this study globin synthesis was investigated in nine patients with heterozygous $\beta$-thalassemia, of whom five patients had sickle thalassemia and four had $\beta$-thalassemia trait. The results confirm the findings in two other patients with $\beta$-thalassemia trait reported earlier from our laboratory (6). In each patient there was decreased total $\beta$-chain synthesis relative to that of $\alpha$-chain in the peripheral blood reticulocytes and balanced synthesis in the bone marrow cells. These findings indicate that the marrow cells of heterozygotes are capable of attaining balanced globin synthesis despite the presence of one thalassemic gene. After loss of the nucleus, the ability to synthesize $\beta$-chain decreases more rapidly than the ability to synthesize $\alpha$-chain.

Despite a variation in clinical severity in the patients with sickle thalassemia, including hemoglobin concentrations ranging from 6.8 to $12.5 \mathrm{~g} / 100 \mathrm{ml}$, there was balanced globin synthesis in the marrow of each patient. Accumulation of excess $\alpha$-chain in bone marrow erythrocytes thus does not appear to contribute to the hemolysis and anemia found in sickle thalassemia. A recent abstract (14) described four patients with sickle thalassemia and hemoglobin concentrations above $10 \mathrm{~g} / 100 \mathrm{ml}$ who similarly had decreased $\beta$-chain synthesis in the peripheral blood and balanced synthesis in the marrow. In contrast a symptomatic patient in that study with a hemoglobin concentration of $8.0 \mathrm{~g} / 100 \mathrm{ml}$ had a higher $\beta / \alpha$ ratio in the bone marrow than in the peripheral blood but did not have balanced synthesis. The reason for the difference between this patient and the nine others who have been studied is not clear.

The mean $\left(\beta^{\mathbf{S}}+\beta^{\mathbf{A}}\right) / \alpha$ radioactivity ratio in the peripheral blood of the patients with sickle thalassemia $(0.75)$ in this study was somewhat higher than the $\beta / \alpha$ ratio in $\beta$-thalassemia trait (0.59). In the group with sickle thalassemia there was no difference between the ratios of the Italian (G. P., 0.75) and the Negro patients. Each of the patients with sickle thalassemia had a thalassemia gene producing some normal $\beta$-chain, although in diminished amounts. Whether the patients with $\beta$-thalassemia trait had a similar type of gene or one causing no $\beta$-chain production at all, perhaps accounting for the difference in ratios, could not be determined.

In patients with sickle thalassemia the $\beta^{\mathrm{s}}$-chain is a convenient marker for the synthesis of globin due to the nonthalassemic $\beta$-allele. In sickle cell heterozygotes who do not have a gene for thalassemia, the ability to synthesize $\beta^{\mathrm{S}}$-, $\beta^{\mathbf{A}}$-, and $\alpha$-chains decreases equally as the red cell matures $(15,16$, and footnote 1$)$. The findings in the five patients with sickle thalassemia differ from those in patients with sickle cell trait. In each patient with sickle thalassemia in the present study, the $\beta^{\mathbf{s}} / \alpha$ ratio in the peripheral blood was reduced from that in the marrow. The rate of synthesis of $\beta^{\mathbf{s}}$-chain thus decreases more rapidly than that of $\alpha$-chain as the cell matures, suggesting a relative instability of the messenger RNA for the nonthalassemic $\beta$-allele compared to that for $\alpha$-chain. In two patients $\boldsymbol{\beta}^{\mathbf{A}}$-chain synthesis was as un-

\footnotetext{
${ }^{1}$ Schwartz, E., and Sh. Friedman. Unpublished observations.
} 
stable as that of $\beta^{\mathrm{s}}$-chain, while in the other three patients $\beta^{\boldsymbol{\Lambda}}$-chain synthesis was as stable as that of $\alpha$-chain. Unstable synthesis of globin chain due to the thalassemic allele, and perhaps instability of the thalassemic messenger RNA, was thus present in only two of the five patients with sickle thalassemia. The two lowest hemoglobin concentrations were present in the patients (M. F. and S. B.) who had instability of synthesis of both $\beta^{\text {s. }}$ and $\boldsymbol{\beta}^{\mathbf{A}}$-chains.

Approximately $38 \%$ of the total hemoglobin in patients with sickle-cell trait is $\mathrm{Hb} \mathrm{S}(17)$. If the average mean cell hemoglobin $(\mathrm{MCH})^{2}$ is $30 \mathrm{pg}$, then there is about $11.4 \mathrm{pg}$ of $\mathrm{Hb} \mathrm{S}$ and $5.7 \mathrm{pg}$ of $\beta^{\mathrm{s}}$-chain per red cell in these patients. The average amount of $\beta^{\mathrm{s}}$-chain per red cell in the patients with sickle thalassemia in the present study was $9.4 \mathrm{pg}$ (7.9-10.3 pg) (calculated from Table I). The nucleated red cells in these patients appear to have compensated in part for the thalassemic defect by increasing the output of the nonthalassemic $\beta$-chain $\left(\beta^{\mathrm{s}}\right)$ by $39-81 \%$. The data available on these patients do not indicate whether there was also stimulation of the thalassemic allele to increase its output slightly since the "normal" amount of synthesis by the thalassemic allele is not known.

The total amount of $\alpha$-chain per cell in heterozygous $\beta$-thalassemia is usually reduced, as indicated by the decreased $\mathrm{MCH}$ found in most patients. Since $\alpha$-chain in the cell may be reduced by as much as one-third $(\mathrm{MCH}=20 \mathrm{pg})$ (calculated from Table I), changes which occur in the peripheral blood reticulocyte alone cannot explain the total reduction. In the bone marrow, where the major part of globin synthesis occurs, there is balanced globin synthesis. Since the $\beta / \alpha$ ratio of one present in nascent globin chains isolated from bone marrow polyribosomes is similar to that in intact cells (18), selective rapid proteolysis of newly formed $\alpha$-chains probably does not occur. It is thus the synthesis of total $\alpha$-chain which is probably reduced in those patients with heterozygous $\beta$-thalassemia who have a decreased mean cell hemoglobin.

The data presented here are consistent with the hypothesis that in heterozygous $\beta$-thalassemia there is compensatory synthesis of $\beta$-chain in the bone marrow cells in response to the presence of the $\beta$-thalassemia defect. The compensatory synthesis primarily involves the nonthalassemic $\beta$-globin allele, perhaps by means of increased synthesis of messenger RNA. There may be a more rapid breakdown of messenger RNA produced in excess by the nonthalassemic $\beta$-chain allele. In some patients, but not in all, there is also a more rapid decrease of synthesis

\footnotetext{
${ }^{2}$ Abbreviation used in this paper: $\mathrm{MCH}$, mean cell hemoglobin.
}

of the $\beta$-chain from the thalassemic allele. The stimulus for compensatory synthesis of $\beta$-chain is uncertain, but it may involve the size of the free $\alpha$-chain pool in the nucleated red cells (19). In many patients $\alpha$-chain synthesis is probably also decreased, accounting for the hypochromia usually found. The final verification of these hypotheses concerning the rates of production and destruction of messenger RNA awaits the development of methods for accurate quantitation of hemoglobin messenger in human red cells.

\section{ACKNOWLEDGMENTS}

We wish to thank Jean Atwater for determinations of $\mathrm{Hb} \mathrm{A}_{2}$ and $\mathrm{Hb} \mathrm{F}$, and Veronica Watson for expert technical assistance.

This work was supported by U. S. Public Health Service Grants AM 12896 and AM 05212, and by a grant from the Cooley's Anemia Foundation.

\section{REFERENCES}

1. Gill, F. M., and E. Schwartz. 1972. Balanced globin synthesis in bone marrow in sickle- $\beta$ thalassemia. Clir. Res. 20: 470 .

2. Bank, A., and P. A. Marks. 1966. Excess $\alpha$ chain synthesis relative to $\beta$ chain synthesis in thalassaemia major and minor. Nature (Lond.). 212: 1198.

3. Weissman, S. M., I. Jeffries, and M. Karon. 1967. The synthesis of alpha, beta, and delta peptide chains by reticulocytes from subjects with thalassemia or hemoglobin Lepore. J. Lab. Clin. Med. 69: 183.

4. Bank, A., A. S. Braverman, J. V. O'Donnell, and P. A. Marks. 1968. Absolute rates of globin chain synthesis in thalassemia Blood. $31: 226$.

5. Kan, Y. W., and D. G. Nathan. 1970. Mild thalassemia: the result of interactions of alpha and beta thalassemia genes. J. Clin. Invest. 49: 635.

6. Schwartz, E. 1970. Heterozygous beta thalassemia: balanced globin synthesis in bone marrow cells. Science (Wash. D. C.). $167: 1513$.

7. Braverman, A. S., and A. Bank. 1969. Changing rates of globin chain synthesis during erythroid cell maturation in thalassemia. J. Mol. Biol. 42: 57.

8. Friedman, S., F. A. Oski, and E. Schwartz. 1972. Bone marrow and peripheral blood globin synthesis in an American Black family with beta thalassemia. Blood $\mathrm{J}$. Hematol. 39 : 785.

9. Cartwright, G. E. 1963. Diagnostic laboratory hematology. Grune and Stratton, Inc., New York. 3rd edition.

10. Gerald, P. S., and L. K. Diamond. 1958. The diagnosis of thalassemia trait by starch block electrophoresis of the hemoglobin. Blood. 13: 61 .

11. Singer, K., A. I. Chernoff, and L. Singer. 1951. Studies on abnormal hemoglobins. II. Their identification by means of the method of fractional denaturation. Blood. 6: 429 .

12. Kan, Y. W., E. Schwartz, and D. G. Nathan. 1968. Globin chain synthesis in the alpha thalassemia syndromes. J. Clin. Invest. $47: 2515$. 
13. Clegg, J. B., M. A. Naughton, and D. J. Weatherall. 1965. An improved method for the characterization of human haemoglobin mutants: identification of $\alpha_{2} \beta_{2}{ }^{05 G L U}$ hemoglobin N (Baltimore). Nature (Lond.). 207: 945.

14. Bank, A., L. W. Dow, M. J. Farace, J. V. O'Donnell, S. Ford, and C. Natta. 1971. Globin chain synthesis in sickle-thalassemia. 14th Annual Meeting of the American Society of Hematology. San Francisco, Calif. 133.

15. Bank, A., J. V. O'Donnell, and A. S. Braverman. 1970. Globin chain synthesis in heterozygotes for $\beta$ chain mutations. J. Lab. Clin. Med. 76: 616.
16. Esan, G. J. F., T. A. Adesina, and L. Luzzatto. 1971. Synthesis of haemoglobins specified by allelic genes in human heterozygotes. Nat. New Biol. 229: 143.

17. Wrightstone, R. N., and T. H. J. Huisman. 1968. Qualitative and quantitative studies of sickle cell hemoglobin in homozygotes and heterozygotes. Clin. Chim. Acta. 22: 593 .

18. Nathan, D. G. 1972. Thalassemia. N. Engl. J. Med. 286: 586.

19. Gill, F. M., and E. Schwartz. 1972. Free alpha chain pool in the bone marrow. Pediat. Res. 6: 370. 